\title{
PENERAPAN METODE KARYAWISATA TERHADAP KEMAMPUAN BERBAHASA EKSPRESIF (BERBICARA) ANAK USIA 5-6 TAHUN DI TK DARUL FALAH PONPES SAMARINDA TAHUN PEMBELAJARAN 2017/2018
}

\author{
Farny Sutriany Jafar \\ PG PAUD FKIP Univ. Mulawarman Samarinda \\ ( farny.sutriany@gmail.com ) \\ Fitriyani Arifin \\ PG PAUD FKIP Univ. Mulawarman Samarinda \\ ( fitriarifin2@gmail.com )
}

\begin{abstract}
The research was intended to know how teacher devise learning of study tours method, to know expressive language skills (speaking) of children with applied method of study tours and to know supporting and inhibitor factors in its application. The research was dome in Darul Falah Ponpes Kindergarten Samarinda on 5-6 years old children in B2 class, with total of student was 13. The research was qualitative research, descriptive with case study approaching. In this research data was acquired using data collecting technic that was observation, interview and documentation. The result shown that (1) teacher devised learning with karyawisata method was establishing program of study tours learning, set the date and destination, permission request, planning implementation of study tours, giving the information to parents of students, preparation of teacher in the class, preparing of tools and material, funding, dividing preceptor group, assign the rules, praying, and explain students about the purpose that need to acquire from karyawisata; (2) expressive language skills (speaking) of children in B2 class with indicators was asking, answering, and retelling, achieving the result of growing as expected $(\mathrm{BSH}) ;(3)$ supporting factors was enthusiastic and student's activeness, good teamwork between foundation, preceptors, parents, and owner of study tours spot, recalling activity in every study tours activity, and teacher's activeness in giving referrals. While inhibitor factors are unpredictable weather, high cost, not all study tours spot has guide, limitation of time in study tours spot, and lack of exemplary in good language using when giving referrals.
\end{abstract}

Keywords : study tours, expressive language (speaking), early childhood

\section{PENDAHULUAN}

Mengoptimalkan kemampuan berbahasa ekspresif (berbicara) pada anak usia 5-6 tahun dengan penerapan metode karyawisata, karena kegiatan belajar melalui bermain secara langsung dan nyata sangat di sukai oleh semua anak yaitu melalui metode karyawisata, dengan berwisata belajar secara langsung akan membantu anak untuk terbiasa saling bertatap muka kepada hal-hal baru yang berada diluar kelas, anak bisa melihat secara langsung, anak bisa merasakan secara langsung dengan obyek nyata, sehingga pemikiran anak akan berkembang luas dan tidak terbatas. Saat ini ada banyak lembaga taman kanak-kanak yang telah 
menerapkan metode karyawisata dan masih ada yang belum menerapkannya.

TK Darul Falah Ponpes Samarinda merupakan lembaga yang peneliti pilih untuk melakukan penelitian. TK Darul Falah Ponpes telah berdiri sejak lama yaitu sejak tahun 1984 dan telah menerapkan metode karyawisata sejak tahun 2014. TK Darul Falah Ponpes Samarinda melaksanakan kegiatan karyawisata pada setiap akhir tema atau puncak tema yang ada, dan dikondisikan kembali pada situasi saat itu, tempat yang di jadikan karyawisata juga setiap tahun berbeda agar anak peserta didik tidak merasa bosan dengan satu tempat tersebut. Kemampuan berbahasa ekspresif (Berbicara) para peserta didik TK Darul Falah Ponpes Samarinda saat ini rata-rata sudah berkembang. Anak mampu menjawab pertanyaan dan menceritakan kembali tentang kegiatan yang telah dilakukannya meskipun dengan jawaban yang sangat singkat, seperti ketika ditanya anak menjawab melakukan kegiatan belajar bernyanyi, bermain alat musik dan mewarnai gambar tanpa menjelaskan kegiatan mewarnai gambar seperti apa yang dilakukan, dan lagu apa yang dinyanyikannya.

Peraturan Menteri Nomor 137 Tahun 2014 pasal 10 ayat 5 menjelaskan tentang indikator pencapaian perkembangan bahasa ekspresif, mencakup kemampuan bertanya, menjawab pertanyaan, berkomunikasi secara lisan, menceritakan kembali yang diketahui, belajar bahasa pragmatic, mengekspresikan perasaan, ide, dan keinginan dalam bentuk coretan. Peneliti memfokuskan pada kemampaun berbahasa ekspresif (berbicara) yaitu kemampuan bertanya, menjawab pertanyaan, dan menceritakan kembali, tentang penerapan metode karyawisata terhadap kemampuan berbahasa ekspresif (berbicara) anak usia 5-6 tahun yang telah diterapkan di TK Darul Falah Ponpes Samarinda Tahun Ajaran 2017/2018. Berdasarkan latar belakang masalah tersebut maka masalah dalam penelitian ini dapat dirumuskan sebagai berikut :

(1) Bagaimana cara guru merancang pembelajaran metode karyawisata terhadap kemampuan berbahasa ekspresif (berbicara) pada anak usia 5-6 tahun di TK Darul Falah Ponpes Samarinda?

(2) Bagaimana kemampuan berbahasa ekspresif (bebicara) anak usia 5-6 tahun di TK Darul Falah Ponpes Samarinda dengan penerapan metode karyawisata? (3) Bagaimana faktor pendukung dan penghambat penerapan metode karyawisata terhadap kemampuan berbahasa ekspresif (berbicara) anak 
usia 5-6 tahun di TK Darul Falah Ponpes Samarinda?

(1) Berdasarkan rumusan masalah tersebut maka Tujuan Penelitian ini adalah sebagai berikut : Untuk mengetahui cara guru merancang pembelajaran metode karyawisata terhadap kemampuan berbahasa ekspresif (berbicara) anak usia 5-6 tahun di TK Darul Falah Ponpes Samarinda.

(2) Untuk mengetahui kemampuan berbahasa ekspresif (berbicara) anak usia 5-6 tahun di TK Darul Falah Ponpes Samarinda dengan penerapan pembelajaran metode karyawisata.

Untuk mengetahui tentang faktor pendukung dan penghambat dalam pelaksanaan penerapan metode karyawisata di TK Darul Falah Ponpes Samarinda.

\section{METODE PENELITIAN}

Jenis penelitian yang digunakan dalam penelitian ini adalah penelitian kualitatif dengan cara deskripsi pengumpulan data utama menggunakan pengamatan, wawancara, atau penelaahan dokumen, menggunakan analisis data secara induktif.

Penelitian dilaksanakan di TK Darul Falah Ponpes Samarinda, alamat di JL. Sukorejo RT. 39 No. 25 Kelurahan Lempake Kecamatan Samarinda Utara.
Subjek penelitian adalah kepala sekolah, guru kelas B2 dan anak kelas B2 berjumlah 13 anak didik.

\section{Prosedur}

Peneliti melakukan wawancara dengan kepala sekolah dan guru kelas B2 untuk memperoleh data mengenai penerapan metode karyawisata terhadap kemampuan berbahasa ekspresif anak usia 5-6 tahun di TK Darul Falah Ponpes Samarinda, peneliti juga menggunakan teknik observasi dan dokumentasi terhadap aktivitas guru dan anak selama kegiatan karyawisata.

Dalam penelitian ini peneliti sebagai instrumen, membuat kesimpulan atas semuanya, dengan menggunakan panduan wawancara, observasi, dan dokumentasi.

Teknik pengumpulan data dalam penelitian kualitatif lebih banyak pada observasi berperanserta, wawancara mendalam, dan dokumentasi.

Aktivitas dalam analisis data, yaitu data collection Kegiatan pengumpulan data diperoleh dari berbagai sumber seperti panduan observasi, panduan wawancara dan dokumentasi. Data reduction Dalam mereduksi data peneliti memfokuskan pada guru kelas B2 dan anak-anak kelas B2 usia 5-6 tahun. Data display Dalam penelitian kualitatif penyajian data 
Jurnal Warna : Jurnal Pendidikan Dan Pembelajaran Anak Usia dini. Maret 2018. Vol 03. No. 01

dilakukan dalam bentuk teks yang bersifat naratif. Conclusion drawing/verification Temuan dapat berupa deskripsi atau gambaran suatu obyek yang sebelumnya masih remangremang atau gelap sehingga setelah diteliti menjadi jelas.

\section{HASIL DAN PEMBAHASAN}

1. Cara guru merancang pembelajaran metode karyawisata terhadap kemampuan berbahasa ekspresif (berbicara) anak usia 5-6 tahun di TK Darul Falah Ponpes Samarinda.

Dalam merancang pembelajaran metode karyawisata yaitu adalah membuat program pembelajaran karyawisata, menetapkan tujuan karyawisata sesuai dengan tema, membuat surat ijin kunjungan dan mengantar surat ijin kunjungan pada tempat tujuan karyawisata yang telah ditetapkan, menetapkan waktu pelaksanaan karyawisata, menginformasikan tentang kegiatan karyawisata kepada orang tua anak didik serta seluruh peserta didik, dan rapat bersama untuk menyiapkan bahan dan alat apa saja yang perlu dipersiapkan dalam proses kegiatan karyawisata. Sebelum berangkat menuju tempat karyawisata guru menyiapkan semua alat dan bahan yang diperlukan untuk kegiatan karyawisata yang telah dirancang sebelumnya, guru menginformsikan tentang peraturan selama kegiatan karyawisata, membagi kelompok anak dengan pembimbingnya, membaca doa sebelum berangkat menuju tempat karyawisata dan guru selalu menginformasikan pada anak didik secara berulang tentang tujuan dari kegiatan karyawisata, guru selalu berusaha agar kegiatan karyawisata dapat terlaksana sesuai dengan harapan.

2. Kemampuan berbahasa ekspresif (berbicara) anak usia 5-6 tahun di TK Darul Falah Ponpes dengan penerapan metode karyawisata.

a.) Kemampuan bertanya

Kegiatan karyawisata kerumah teman, kemampuan bertanya pada anak muncul ketika guru selesai menjelaskan dan mengenalkan nama orangtua firki serta anggota keluarga firki, salah satu anak didik yang bernama alfin kelas B2 bertanya pada ibu firki, berikut adalah percakapan antara alfin dan ibu firki :

Guru :(ketika guru melihat alfin mengangkat tangannya) Alfin mau bertanya ?

Alfin :Iyaa.

Guru :Ingin betanya pada siapa

Alfin :Ibu firki.

Guru :Silahkan maju kesini, alfin mau betanya apa ?

Ibu Firki :Ayo tanya apa? 
Alfin :Bapak firkinya kerja apa ?

Ibu Firki :Ayah firki kerja listrik.

Guru :Nah alfin tau listrik itu apa ?

Alfin :Naahhhh aku tau,, Bisa.

Listrik itu setrum !

Guru :Strum itu untuk apa saja ?

Alfin :Wastafel,eehhhmmmm (Alfin berusaha mengingat).

Bapaknya firki ada?

Ibu Firki :Ada didalam .

Guru :Kalau mati lampu ?

Alfin :Pakai lilin. Kalau rumah alfin itu kalau mati lampu pakai janset.

Kemampuan bertanya pada anak juga muncul ketika diperjalanan akan menuju tempat karyawisata, seperti ketika diperjalanan akan berkaryawisata ke Abihira Herba Center yang jaraknya tidak jauh dari sekolah sehingga ditempuh dengan berjalan kaki, anak didik yang bernama robby melihat ke atas langit dan tiba-tiba betanya pada guru tentang awan yang mengikuti robby, berikut percapakan robby anak didik kelas B2 dan guru.

Guru :(mengajak anak didik untuk bernyanyi)

Robby :Bunda kenapa awannya jalan mengikuti kita?

Guru :Awan ? (guru terlihat terkejut dengan pertanyaan robby)
Robby :Itu na bunda di atas ? (robby menunjukan awan yang ada di atas langit)

Anak Didik :Mana robby awannya ? (teman-teman yang lain ikut bertanya)

Robby : Itu nahh liat !

Anak Didik :Iya bun, awannya jalan lihat itu

Guru :Subahanallah, sungguh besar kuasa allah. Awannya ikut berjalan bersama kita, karena ingin melindungi kita dari panas matahari. Mari ucapkan terimakasih pada awannya.

Robby :Horreeee (Robby berteriak dengan senang) Terimakasih awan.

Anak Didik :Terimakasih awan dada... (anak didik mengucapkan terimakasih dan melambaikan tangan mereka).

b.) Kemampuan menjawab pertanyaan Kegiatan karyawisata yang dilaksanakan di Abihira Herba Center, pemilik abihira sakaligus yang menjadi narator dalam pelaksanaan karyawisata memberikan penjelasan pada anak didik tentang jenis produk olahan herbal untuk anak-anak, bahan-bahannya, dan manfaatnya. Setelah selesai menjelaskan kemudian narator memberikan pertanyaan, bagi yang bisa menjawab akan diberi hadiah dari narrator. Berikut percakapan antara 
narrator dengan anak didik kelas B2 yang bernama syafira:

Narator :Sebutkan salah satu bahan dari pembuat magh kids ?

Ayo siapa !

Guru :Ayo angkat tangan!

Syafira :(beberapa anak mengangkat tangan, dan syafira adalah anak didik yang terpilih untuk menjawab kedepan.

Narator :Siapa namanya ?

Syafira :Safira.

Narator :Sebutkan salah satu bahan pembuat magh kids ?

Syafira :Mangga.

Narator :Diulang lagi apa?

Syafira :Mangga.

Guru :Temunya.

Narator :Apa?

Syafira :Temu mangga.

Narator :Yaa jadi ada beda ya temu mangga dengan mangga, bukan mangga yang buah mangga ya. Ya nanti adek-adek liat ya bentuk tanaman temu mangga.

Kegiatan karyawisata ke Kampung Dongeng kemampuan menjawab pertanyaan pada anak didik kelas B2 terlihat kembali ketika narrator menceritakan dongeng tentang nenek dan cucunya si dodo dengan media boneka tangan, narrator kemudian menanyakan pada anak didik tentang cerita dongeng tersebut, berikut percakapan anak didik kelas B2 Aris dengan narrator :

Narator :(dengan suara khas mendongeng) coba tanya sama teman-teman mu, kalo dodo disuruh ke warung dodo pulang bawa apa?

Guru :Bawa apa kalo pulang hayo !

Narator :Kalau kata nenek, kalo dodo disuruh pergi ke warung pulang dodo bawa apa ?

Aris :Bawa bombon sama jajan hahahahahaha

Guru :Waahhh aris ketahuan sering seperti itu yaa!

Aris :Iya, saya suka saya suka.

Narator :Iya benar sekali, dodo juga bawa bombon setiap nenek suruh beli ke warung (dengan bahasa khas mendongeng).

Aris :Enak enak nyam nyam.

Guru :Kalo diminta tolong untuk beli apa belikan dulu apa yang disuruh baru sisanya aris boleh belanjakan beli bombon.

c.) Kemampuan menceritakan kembali

Kegiatan karyawisata ke Islamic centre telah selesai, semua guru dan anak didik kembali ke kendaraan untuk pulang. Ketika diperjalanan pulang salah satu anak didik yang bernama andini kelas B2 mengungkapkan keinginannya untuk 
bercerita. Berikut percakapan Andini dan guru :

Andini :(ketika berada diatas transportasi diperjalanan pulang dari karyawisata) Aku punya cerita bun. Bunda !

Guru :(guru melihat anak didik dengan tersenyum) iya boleh.

Andini :Tadi aku baca buku. Aku baca buku tapi aku tidak tau ceritanya.

Guru :Andini lupa ? jadi mau cerita apa ?

Andini :Tapi aku masih ingat. Kaikainya menikah sama orang cantik dia ratu, terus itu ratunya gak kenal sama suaminya sendiri karena sudah pisah lama. Pisah lima hari.

Guru :Jadi ratunya menikahnya dengan siapa ?

Andini :Suaminya ada dua. Tadi baca buku burung juga dia itu di sarangnya menangis, dia jagain suaminya, suaminya lagi sakit tertembak.

Guru :Siapa yang menembak ?

Andini :Orang yang nembak, terus mau nembak lagi.

Guru :Seru yaa buku yang dibaca andini.

Dihari lain setelah melaksanakan karyawisata kerumah teman, keesokan harinya diruang kelas guru membahas kembali tentang kegiatan karyawisaa ke Rumah Teman yang telah dilaksanakan dengan tema keluargaku yaitu cara menyanyangi ayah dan ibu. Pada saat guru sedang menjelaskan salah satu anak didik kelas B2 yang bernama yuki berkata bunda aku ingin bercerita. Berikut percakapan yuki dengan guru dalam menceritakan kembali pengalaman tentang ayah yuki :

Yuki :Bun, aku mau bercerita.

Guru :Iya. (Guru menjawab dengan tersenyum).

Yuki :Pada jaman dahulu ayah ku kerja di Balikpapan, ayahku menelfon ibuku ayahku masuk hutan-hutan dan nyasar, mobil ayahku masuk jurang. Kudoakan semoga selamat, terus ditarik mobil tronton.

Guru :Didoakan tidak bapaknya ?

Yuki :Iya.

Guru :Mendoakannya bagaimana ?

Yuki :Ya Allah semoga bapak selamat dijalan.

Guru :Aminnnn. Bunda sedih mendengar ceritanya yuki, bunda terharu, yuki anak hebat anak sholeh. Kenapa ? Karena yuki selalu mendoakan orangtuanya. Siapa yang bisa doa kedua orangtua?

Anak didik : Saya ! ( seluruh anak didik menjawab bersama dan 
mengucapkan doa kedua orangtua bersama-sama)

Kemampuan berbahasa ekspresif (berbicara) pada anak kelompok B2 TK Darul Falah Ponpes Samarinda seperti yang telah dijelaskan diatas dan penilaian dari guru kelas B2 bahwa kemampuan berbahasa ekspresif (berbicara) pada anak kelas B2 TK Darul Falah Ponpes Samarinda sudah mencapai hasil perkembangan BSH yaitu berkembang sesuai harapan, dengan indikator perkembangan yaitu kemampuan bertanya, menjawab pertanyaan, dan menceritakan kembali tentang apa yang telah dilakukannya, hasil penialaian kemampuan berbahasa ekspresif (berbicara) anak kelas B2 yang menunjukan telah mencapai hasil BSH dapat dilihat dari tabel di bawah ini.

Tabel 4.3 Hasil Observasi Kemampuan

Berbahasa Ekspresif (Berbicara)

\begin{tabular}{|c|c|c|c|c|c|c|}
\hline \multicolumn{7}{|c|}{$\begin{array}{c}\text { Kemampuan Berbahasa Ekspresif (berbicara) Anak B } 2 \text { TK } \\
\text { Darul Falah Ponpes }\end{array}$} \\
\hline \multirow{4}{*}{$\begin{array}{l}\text { Nama } \\
\text { Anak } \\
\text { Didik }\end{array}$} & \multicolumn{6}{|c|}{$\begin{array}{l}\text { Observasi Kemampuan Bertannya, Menjawab } \\
\text { Pertanyaan, Menceritakan Kembali }\end{array}$} \\
\hline & Min & Min & Min & Min & Min & Min \\
\hline & ggu & ggu & ggu & ggu & ggu & ggu \\
\hline & ke 1 & ke 2 & ke 3 & ke 4 & ke 5 & ke 6 \\
\hline Yuki & MB & BSH & - & BSH & BSH & BSH \\
\hline Erik & MB & $\mathrm{MB}$ & $\mathrm{MB}$ & $\mathrm{MB}$ & $\mathrm{BSH}$ & $\mathrm{BSH}$ \\
\hline Robby & $\mathrm{BSH}$ & $\mathrm{BSH}$ & $\mathrm{BSH}$ & - & BSH & BSH \\
\hline Keiysa & MB & $\mathrm{BSH}$ & $\mathrm{BSH}$ & $\mathrm{BSH}$ & $\mathrm{BSH}$ & $\mathrm{BSH}$ \\
\hline Aris & BSH & MB & MB & - & BSH & BSH \\
\hline Alfin & MB & $\mathrm{BSH}$ & $\mathrm{BSH}$ & $\mathrm{BSH}$ & $\mathrm{BSH}$ & $\mathrm{BSH}$ \\
\hline Maulana & BSH & BSH & MB & BSH & BSH & BSH \\
\hline Syafiera & MB & $\mathrm{MB}$ & $\mathrm{MB}$ & MB & $\mathrm{BSH}$ & $\mathrm{BSH}$ \\
\hline Anjani & $\mathrm{BSH}$ & $\mathrm{MB}$ & $\mathrm{BSH}$ & $\mathrm{BSH}$ & $\mathrm{BSH}$ & $\mathrm{BSH}$ \\
\hline Kania & - & MB & BSH & BSH & BSH & BSH \\
\hline Andini & $\mathrm{BSH}$ & $\mathrm{BSH}$ & $\mathrm{BSH}$ & $\mathrm{BSH}$ & $\mathrm{BSH}$ & $\mathrm{BSH}$ \\
\hline Heni & MB & MB & - & MB & BSH & - \\
\hline Afina & MB & $\mathrm{BSH}$ & - & MB & $\mathrm{BSH}$ & $\mathrm{BSH}$ \\
\hline
\end{tabular}

Keterangan : Nilai $1=B B$, Nilai $2=M B$,

Nilai $3=$ BSH, Nilai 4= BSB.
3. Faktor pendukung dan penghambat penerapan metode karyawisata terhadap kemampuan berbahasa ekspresif (berbicara) anak usia 5-6 tahun di TK Darul Falah Ponpes Samarinda.

Peneliti menyimpulkan bahwa penerapan metode karyawisata terhadap kemampuan berbahasa ekspresif (berbicara) anak usia 5-6 tahun di TK Darul Falah Ponpes Samarinda sudah terlaksana dengan baik, namun menurut peneliti masih bisa dimaksimalkan lagi dan ditingkatkan untuk menjadi semakin lebih baik lagi. Peneliti menemukan faktor pendukung dan penghambat dalam penerapan metode karyawisata terhadap kemampuan berbahasa ekspresif (berbicara) anak usia 5-6 tahun di TK Darul Falah Ponpes Samarinda, akan tetapi kepala sekolah dan guru tetap selalu bersemangat dan berinovasi agar kegiatan karyawisata bisa tercapai sesuai dengan tujuan yang diharapakan.

a.) Faktor pendukung penerapan metode karyawisata

1.) Dengan pelaksanaan program pembelajaran karyawisata mampu menjadikan sekolah TK Darul Falah Ponpes menjadi lebih maju dan berkembang.

2.) Kerjasama antara kepala sekolah, guru, dan orangtua anak didik menjadikan kegiatan karyawisata 
bisa terlakasana, mulai dari kesiapan pelaksanaan, penyediaan alat dan bahan, dan pendanaan.

3.) Pelaksanaan pembelajaran karyawisata memberikan pengalaman yang berkesan pada anak untuk menumbuhkan minat dan bakat pada diri anak. Informasi yang bisa diperoleh anak dengan sebenar-benarnya secara langsung membantu anak untuk mendapatkan jawaban atas pertanyaan yang ada pada diri anak.

b.) Faktor penghambat penerapan metode karyawisata

1.) Cuaca dan lokasi sekolah dengan tempat yang akan dijadikan tempat tujuan karyawisata.

2.) Persiapan fisik tenaga pendidik dalam pelaksanaan karyawisata.

3.) Biaya yang harus disiapkan dalam kegiatan karyawisata atau pendanaan.

Hasil observasi peneliti juga menemukan faktor pendukung dan penghambat kemampuan berbahasa ekspresif (berbicara) anak usia 5-6 tahun di TK Darul Falah Ponpes Samarinda dengan penerapan metode karyawisata adalah

a.) Faktor pendukung kemampuan berbahasa ekspresif (berbicara) anak dengan penerapan metode karyawisata
1.) Antusias anak sangat tinggi pada setiap hal baru yang mereka temukan.

2.) Keaktifan pendidik dalam mengarahkan anak didik selama kegiatan karyawisata.

3.) Kegiatan recalling pada setiap pelaksanaan karyawisata.

Faktor penghambat kemampuan berbahasa ekspresif (berbicara) anak usia 5-6 Tahun di TK Darul Falah Ponpes Samarinda dengan penerapan metode karyawisata

1.) Pemandu karyawisata.

2.) Waktu yang sangat singkat dalam pelaksanaan karyawisata.

3.) Sikap keteladanan guru dalam menggunakan bahasa pada anak.

\section{Pembahasan}

Penulis dapat menyimpulkan merancang pembelajaran menggunakan karyawisata untuk bisa tercapai sesuai harapan yang perlu dipersiapkan guru adalah menyiapkan bahan dan alat yang diperlukan selama karyawisata, mengkordinasikan pendanaan antara yayasan, sekolah, dan orangtua peserta didik, menginformasikan kepada peserta didik tentang program kegiatan kunjungan karyawisata, dan menjelaskan kepada peserta didik tentang tujuan yang ingin dicapai dalam kegiatan karyawisata yang akan dilaksanakan. Pelaksanaan kegiatan 
karyawisata dilakukan sesuai dengan rancangan yang telah disepakati sebelumnya, guru menyiapkan segala keperluan alat dan bahan yang digunakan selama karyawisata yaitu menyiapkan alat transportasi, menyiapkan souvenir atau kenangkenangan yang akan diberikan kepada pemilik tempat karyawisata, menyiapkan konsumsi untuk anak peserta didik, obat-obatan yang dibutuhkan, alat pengeras suara, dan keperluan lainnya yang dirasa perlu, menentukan kelompok pembimbing, menginformasikan aturan-aturan tata tertib yang boleh dan tidak boleh dilakukan peserta didik selama kegiatan karyawisata, berdoa sebelum berangkat menuju tempat karyawisata, naik ke alat transporatsi dengan pembimbing yang telah ditentukan, bernyanyi selama diperjalanan menuju tempat karyawisata, dan menginforamsikan kepada peserta didik secara berulang kali tentang tujuan yang ingin dicapai dari kegiatan karyawisata. Sesuai dengan pendapat menurut Moeslichatoen (2004:88) pelaksanaan karyawisata sesuai dengan rancangan karyawisata adalah :

a. Menyiapkan semua peralatan dan bahan sesuai dengan rancangan. b. Kegiatan menentukan kelompokkelompok anak serta pembimbingnya.

c. Sebelum berangkat menuju sasaran karyawisata didahului dengan membaca doa bersama sesuai dengan keyakinan masing-masing.

d. Dalam perjalanan anak diajak bernyanyi dengan lagu-lagu sesuia dengan tema karyawisata.

e. Mengarahkan perhatian anak pada sasaran yang harus diamati yang merupakan bagian yang terkandung dalam tujuan dan tema yang sudah ditetapkan.

Kemampuan berbahasa ekspresif (berbicara) anak muncul bukan hanya ketika diperjalanan menuju tempat karyawista atau pada saat ditempat karyawisata saja, akan tetapi ketika setelah kegiatan karyawisata yaitu pada saat anak bertemu dengan keluarganya dan ketika pembelajaran dikelas setelah dilaksanakannya karyawisata. Berbahasa ekspresif (berbicara) dalam kemampuan bertanya salah satunya muncul pada kegiatan karyawisata dirumah teman, setelah guru menjelaskan tentang nama anggota keluarga dan jumlah anggota keluarga firki kemudian guru memberikan kesempatan pada anak didik untuk bertanya. Anak didik kelas B2 yang bernama alfin mengangkat tangannya dan mengajukan pertanyaan 
pada ibu firki "Bapaknya firkinya kerja apa ? "ayah firki bekerja ditempat listrik. Alfin kembali bertanya “ Bapaknya firki ada? "ada didalam.

Berbahasa ekspresif (berbicara) pada kemampuan menjawab pertanyaan salah satunya muncul pada kegiatan karyawisata ke Abihira Herba Center, pertanyaan dari narrator "sebutkan salah satu bahan membuat magh kids?" syafira kelas B2 menjawab mangga karena jawaban belum tepat guru dan narrator akhirnya memberi arahan pada syafira jawabanya yaitu salah satu bahan pembuat magh kids adalah temu mangga. Berbahasa ekspresif (berbicara) pada kemampuan menceritakan kembali salah satunya muncul pada kegiatan karyawisata di Islamic centre, anak didik bernama alika menceritakan tentang buku yang dilihatnya "putri yang menikah sama maling, maling pertamanya itu dia tidak pulang, kemudian malingnya pulang kepenjara lagi, dan putrinya pulang masak dirumah setelah itu lupa".

Masitoh dalam Siti Aisyah (2006:1.3) menegaskan bahwa pembelajaran yang paling efektif untuk anak usia TK adalah suatu kegiatan yang konkret dengan pendekatan yang berorientasi bermain. Peraturan Menteri Nomor 137 Tahun 2014 pasal 10 ayat 5 menjelaskan tentang indikator pencapaian perkembangan Bahasa Ekspresif, mencakup kemampuan bertanya, menjawab pertanyaan, berkomunikasi secara lisan, menceritakan kembali yang diketahui, belajar bahasa pragmatic, mengekspresikan perasaan, ide, dan keinginan dalam bentuk coretan.

Menurut hasil pengamatan peneliti, berikut faktor pendukung penerapan metode karyawisata terhadap kemampuan berbahasa ekspresif (berbicara) anak usia 5-6 tahun di TK Darul Falah Ponpes Samarinda yaitu :

a. Kerjasama yang terjalin sangat baik antara yayasan dan sekolah.

b. Sikap komunikatif yang dilakukan guru dalam mengarahkan anak didik pada tujuan yang ingin dicapai dalam kegiatan karyawisata, menjadikan kemampuan berbahasa ekspresif anak berkembang.

c. Partisipasi orangtua terkait pendanaan sangat membantu program kegiatan karyawisata.

d. Anak memperoleh informasi dengan sebenar-benarnya secara langsung, mendapatkan jawaban dari pertanyaan pada dirinya. Antusias dan rasa ingin tahu anak yang tinggi, menjadikan aspek perkembangan bahasa pada anak bisa berkembang dengan baik, keaktifan anak didik dalam melihat segala sesuatu yang 
ditemuinya menumbuhkan sikap rasa ingin tahu pada anak semakin meningkat.

e. Setiap pelaksanaan karyawisata dilakukan kegiatan recalling, kegiatan tersebut sangat membantu anak didik dalam mengekspresikan ide dan pikirannya, membantu anak untuk mengingat kembali apa yang belum tertuangakan dalam pikiran anak menjadikan bahasa ekspresif (berbicara) pada anak bisa lebih berkembang.

Hildebrand dalam Moeslichatoen (2004:71) Karyawisata bagi anak TK dapat digunakan merangsang minat mereka terhadap sesuatu, memperluas informasi yang telah diperoleh di kelas, memberikan pengalaman mengenal kenyataan yang ada, dan dapat menambah wawasan.

Faktor penghambat penerapan pembelajaran metode karyawisata terhadap kemampuan berbahasa anak usia 5-6 tahun di TK Darul Falah Ponpes Samarinda adalah:

a. Cuaca yang tidak menentu sewaktuwaktu bisa terkendala banjir, faktor cuaca berpengaruh besar dalam pelaksanaan karyawisata di TK Darul Falah Ponpes Samarinda.

b. Pendidik harus perlu benar-benar mempersiapkan fisik tenaga dengan baik agar program pembelajaran metode karayawisata bisa tercapai sesuai harapan.

c. Pendanaan sangat berpengaruh karena karyawisata tidak akan terlaksana dengan baik jika tidak ada dana.

d. Pemandu karyawisata dirasa sangat membantu guru untuk mengarahkan apa saja yang dirasa perlu untuk diketahui oleh anak, yang juga belum diketahui oleh guru.

e. Keterbatasan waktu anak didik untuk mencoba semua hal yang ada ditempat karyawisata, sehingga rasa ingin tahu pada anak masih banyak yang belum terpecahkan.

f. Sikap keteladanan guru dalam penggunaan bahasa yang disampaikan pada anak, kehati-hatian dalam penggunaan bahasa sangat diperlukan.

Roestiyah

(2008:86-88) menyebutkan tentang kelebihan dan kekurangan dari metode karyawisata adalah : Kelebihan dari metode karyawisata yaitu 1.) siswa dapat berpartisipasi dalam berbagai kegiatan yang dilakukan oleh para petugas pada obyek karyawisata. Siswa dapat melihat berbagai kegiatan para petugas secara individu maupun secara kelompok dan dihayati secara langsung, yang akan memperdalam dan memperluas pengalaman mereka. 2.) Dalam 
kesempatan ini siswa dapat bertanya jawab, menemukan sumber informasi yang pertama untuk memecahkan segala persoalan yang dihadapi. 3.) Dengan obyek yang ditinjau itu siswa dapat memperoleh bermacam pengetahuan dan pengalaman yang terintegrasi, yang tidak terpisah-pisah dan terpadu.

Kekurangan dari metode karyawisata, karyawisata biasanya dilakukan diluar sekolah. Sehingga mungkin jarak tempat itu sangat jauh dari sekolah, maka perlu menggunakan transportasi, hal itu pasti memerlukan biaya yang sangat besar. Juga pasti menggunakan waktu yang lebih panjang dari pada jam sekolah, maka jangan sampai mengganggu kelancaran rencana pelajaran yang lain. Biaya yang tinggi kadang-kadang tidak terjangkau oleh siswa maka perlu bantuan dari sekolah.

\section{PENUTUP}

\section{Kesimpulan}

Berdasarkan hasil penelitian yang peneliti lakukan ditarik kesimpulan yaitu pertama bagaimana cara guru merancang pembelajaran menggunakan metode karyawisata terhadap kemampuan berbahasa ekspresif (berbicara) pada anak, adalah membuat program pmbelajaran karyawisata, menetapkan tujuan karyawsiata, permintaan izin, menetapkan waktu pelaksanaan karyawista, menyiapkan pendanaan, menyiapkan alat dan bahan seperti transportasi, souvenir, konsumsi, pengeras suara, tali panjang, obatobatan, serta perisiapan lainnya, guru menginformasikan

peraturan karyawsiata, membagi anak didik dengan pembimbingnya, membaca doa, bernyanyi ketika diperjalanan dan menginformasikan pada anak didik tentang tujuan yang ingin dicapai dari kegiatan karyawsisata. Rumusan masalah ke dua hasil penilaian menunjukan kemampuan berbahasa ekspresif (berbicara) anak kelas B2 sudah mencapai hasil perkembangannya adalah BSH yaitu berkembang sesuai harapan dengan bahasa ekspresif (berbicara) pada anak yang muncul pada saat ditempat karyawisata, merespon secara baik segala pertanyaan yang diberikan, bercerita tentang apa saja yang telah dilakukan selama kegiatan karyawisata. Rumusan masalah yang terahir faktor pendukung penerapan metode karyawisata terhadap kemampuan berbahasa ekspresif (berbicara) anak usia 5-6 tahun di TK Darul Falah Ponpes Samarinda, mutu pendidikan sekolah semakin meningkat, antusias dan keaktifan anak didik, memberikan pengalaman yang menarik bagi anak, membantu anak menemukan minat pada dirinya, kegiatan recalling 
pada setiap pelaksanaan karyawisata, dan kerjasama yang baik antara yayasan, sekolah, guru dan orangtua peserta didik. Faktor penghambat diantaranya faktor cuaca, lokasi karyawsiata, tenaga pendidik, pendanaan, pemandu karyawisata yang tidak semua tempat karyawisata memberikan pemandu karyawisata, waktu yang terbatas pada pelaksanaan karyawisata, dan sikap keteladanan yang dimiliki oleh pendidik dalam mengarahkan anak peserta didiknya.

\section{Saran}

Bagi peneliti, diharapkan untuk mampu mengembangkan suatu metode karyawisata dalam suatu model pembelajaran di TK, diharapkan untuk bisa meneliti tentang bahasa ekspresif yaitu mengekspresikan perasaan, ide, keinginannya dalam bentuk coretan atau tulisan dan mengetahui pengaruh metode karyawisata terhadap aspekaspek perkembangan anak usia dini, dengan menggunakan metode penelitian eksperimen.

\section{DAFTAR PUSTAKA}

Aisyah, Siti. 2006. Pembelajaran Terpadu. Jakarta: Universitas Terbuka.

Masitoh. 2009. Strategi Pembelajaran TK. Jakarta:Universitas Terbuka.

Moeslichatoen, R. 2004. Metode Pengajaran Di Taman KanakKanak. Jakarta: Rineka Cipta.

N.K, Roestiyah. 2008. Strategi Belajar Mengajar. Jakarta: Rineka Cipta.

Palenewen, Evie. 2015.Balajar Sains Melalui Bermain. Mulawarman University Press. Samarinda

Peraturan Menteri Pendidikan Dan Kebudayaan Republik Indonesia, Nomor 146 Tahun 2014, Kurikulum 2013 Pendidikan Anak Usia Dini.

Peraturan Menteri Pendidikan Dan Kebudayaan Republik Indonesia, Nomor 137 Tahun 2014, Standar Nasional Pendidikan Anak Usia Dini.

Riadi, Rika Mastiha Aisti.2016.Skripsi Peningkatan Kemampuan Bahasa Anak Usia Dini Melalui Metode Bermain Peran Di Kelompok B PAUD. Nusa Indah

Tenggarong. Samarinda: Universitas Mulawarman.

Sugiyono. 2015. Metode Penelitian Pendidikan Pendekatan Kuantitatif, Kualitatif, dan $R \& D$. Bandung: Alfabeta.

Susanto, Ahmad. 2011. Perkembangan Anak Usia Dini Pengantar Dalam Berbagai Aspeknya. Jakarta: Kencana Prenada Group.

Suyadi dan Maulidya Ulfah. 2013. Konsep Dasar PAUD. Bandung: Remaja Rosdakarya.

Suyadi. 2014. Teori Pembelajaran Anak Usia Dini. Bandung: Remaja Rosdakarya. 